\author{
CRISTINA RATTO \\ FACULTAD DE FILOSOFÍA Y LETRAS, UNAM
}

\title{
La ciudad dentro de la gran ciudad Las imágenes del convento de monjas en los virreinatos de Nueva España y Perú
}

$\mathrm{L}$ A DESCRIPCIÓN DE LAS CIUDADES VIRREINALES en términos de grandes urbes dominadas por un número sorprendente de iglesias y conventos ha sido una imagen visual y literaria muy frecuente. Un rasgo que ya desde finales del siglo xvi fue motivo de orgullo para propios y sorprendió a los extranjeros. Dentro de este paisaje, unos y otros coincidieron en destacar, a lo largo del tiempo, la presencia insoslayable de los conventos de monjas. La revisión de crónicas y textos literarios revela que ellos fueron un tópico recurrente en el discurso laudatorio de la ciudad como urbs y civitas.

La idea de ciudad durante el antiguo régimen surgió de la fusión de conceptos provenientes de la Antigüedad clásica y del pensamiento cristiano. La urbs, como entorno construido, y la civitas, como comunidad humana, fueron las dos caras de la moneda. Así, la exaltación del aspecto físico, mucho más que la descripción puntual del espacio habitado, fue sobre todo una metáfora con la que se destacó la piedad y la nobleza de sus habitantes. La civitas tomaba cuerpo en la arquitectura: la traza de una ciudad, la suntuosidad de un palacio, la disposición de una plaza hablaban de la pujanza de sus vecinos y la policía de su gobierno. Sus conventos, sus iglesias monumentales, sus hospitales expresaban elocuentemente la nobleza y la piedad tanto de los individuos que las patrocinaban como de la comunidad en su conjunto. ${ }^{\mathrm{I}}$ La cultura virreinal

I. Richard Kagan, Imágenes urbanas del mundo hispánico. I493-I780, Madrid, El Viso, I998, pp. 48-50. 
nació dentro de este sistema de conceptos e inmediatamente los hizo suyos; de tal modo que la ciudad fue uno de los símbolos de cohesión más fuertes para los nacidos en el Nuevo Mundo.

\section{Los conventos de monjas en las laudes urbanas virreinales}

Las primeras imágenes de la ciudad de México surgieron tras la gesta "heroica" de la conquista de Tenochtitlan y al amparo de su pasado mítico. Los protagonistas de aquellos acontecimientos pusieron énfasis tanto en la grandiosidad de la ciudad finalmente sojuzgada como en la rapidez con que la nueva capital comenzó a levantarse sobre las ruinas de la urbe mexica. Fue el mismo Hernán Cortés quien dio una primera imagen de la pujanza de la urbs que tomaba forma al tiempo que los conquistadores se convertían en vecinos.

y se repartieron los solares por los vecinos, y a cada uno de los que fueron conquistadores, en nombre de vuestra real alteza, yo di un solar, por lo que en ella había trabajado, demás del que se les ha de dar como a vecinos, que han de servir, según orden de estas partes, y hanse dado tanta prisa en hacer las casas de los vecinos, que hay mucha cantidad de ellas hechas, y otras que llevan ya buenos principios; y porque hay mucho aparejo de piedra, cal y madera, y de mucho ladrillo, que los naturales labran, que hacen todos tan buenas y grandes casas, que puede creer vuestra sacra majestad que hoy en cinco años será la más noble y populosa ciudad que haya en lo poblado del mundo, y de mejores edificios. ${ }^{2}$

En igual medida, Bernal Díaz del Castillo destacó la diligencia con que sus compañeros de armas, a instancias de Hernán Cortés, se habían dado a la tarea de levantar la nueva ciudad tras la devastación.

mandó [...] que limpiasen todas las calles de los cuerpos y cabezas de muertos, que los enterrasen, para que quedasen limpias, y sin hedor ninguno la ciudad, y que todas las puentes y calzadas que las tuviesen muy bien aderezadas como de antes estaban; y que los palacios y casas las hiciesen nuevamente, que dentro de dos meses se volviesen

2. Hernán Cortés, "Cuarta carta de Hernán Cortés al emperador Carlos V, Tenuxtitlan, I5 de octubre de I524”, en Cartas de relación, México, Porrúa, 2004, pp. 249-250. 
a vivir en ellas, y les señaló en qué parte habían de poblar y la parte que habían de dejar desembarazada para que poblásemos nosotros. ${ }^{3}$

La carta de Hernán Cortés constituye en esencia un informe dirigido al rey. En ella se dejan ver tanto las consecuencias de las hazańas militares como el resultado de lo que podrían considerarse las primeras medidas del buen gobierno. Por su parte, Bernal Díaz del Castillo buscó hacer presente a los "verdaderos" protagonistas de las acciones militares: los hombres que, al mando de Cortés, tomaron posesión de los nuevos territorios para la Corona y la Iglesia. En este sentido, ambos testimonios deben entenderse como formas de promoción personal o de un grupo y, por tanto, contaminadas por las hipérboles y las amplificaciones necesarias para alcanzar sus objetivos. Sin embargo, los dos autores no dudaron en valerse, entre otros recursos, de la descripción de la naciente urbs, para destacar la calidad de su civitas.

Ya desde la segunda mitad del siglo XVI, al tópico de la rápida conformación del espacio urbano se une la imagen de una ciudad comparable con las más importantes del Viejo Mundo. Un viajero inglés, de paso por la capital novohispana, no dudó en destacar, con evidente asombro: "La ciudad va muy de prisa en edificar conventos de monjas y frailes, e iglesias y lleva traza de ser con tiempo la ciudad más populosa del mundo, según se cree”. ${ }^{4}$ De tres tópicos frecuentes en los discursos modernos de la laudatio urbis se sirvió el viajero: la dimensión presente y, sobre todo, futura de la capital, sus iglesias y, en igual medida, sus conventos de frailes y monjas.

Posiblemente haya sido Francisco Cervantes de Salazar —a mediados del siglo XVI- uno de los primeros hombres de letras en celebrar la riqueza arquitectónica de la ciudad de México como expresión de la jerarquía de su civitas. En el "Diálogo segundo" de su obra México en I554, tres paseantes recorren el cuadro central de la capital novohispana. Los personajes siguen un itinerario diseñado en función de una descripción de la ciudad, sus edificios, sus instituciones y sus vecinos: "llevemos a pasear por México, cual nuevo Ulises, a nuestro amigo $[\ldots]$ para que admire la grandeza de tan insigne ciudad.” [...]

3. Bernal Díaz del Castillo, Historia verdadera de la conquista de la Nueva España [1632], México, Porrúa, 2004, pp. 373-374.

4. Joaquín García Icazbalceta, "Viaje de Robert Thomson, comerciante, a la Nueva España, en el año de 1555 . Con varias observaciones acerca del país y relación de diversos sucesos que acaecieron al viajero", en Relaciones de varios viajeros ingleses en la ciudad de México y otros lugares de la Nueva España, Madrid, Porrúa/Turanzas, I963, p. 29. 
Estamos ya en la plaza [...] no recuerdo ninguna, ni creo que en ambos mundos pueda encontrarse igual. [...] ¡Qué adornada de altos y soberbios edificios!"’

De manera puntual, Cervantes de Salazar se refirió a la singularidad de la traza de la joven capital y comparó sus edificios con los de la Roma clásica y los de la floreciente Toledo. Destacó la amplitud de la Plaza Mayor y sus portales, sus acequias, sus suntuosos palacios, su universidad — recién fundada-, los grandes conventos de frailes y las bucólicas fincas suburbanas. ${ }^{6}$ De tal forma que, a sólo 30 años de su fundación, México aparecía como una ciudad centenaria. Aún más, en su descripción de la capital novohispana no olvidó destacar "Éste es el monasterio de las vírgenes consagradas al Señor. Saludemos la imagen de Nuestra Señora, colocada sobre la puerta". ${ }^{7}$

Así, en el recorrido, la primera comunidad de monjas de clausura se consideró un hito digno de mención que, como otros edificios significativos, servía para realzar la dignidad de la capital y sus vecinos. ${ }^{8}$ Poco después, el mismo Cervantes de Salazar volvió sobre el tópico de las religiosas en el contexto de otra descripción de la ciudad. Esta vez para señalar el rápido crecimiento de aquel primer convento, elogiar la "calidad" de sus miembros — comparándolo con los castellanos-y hacer hincapié en la construcción de su nuevo edificio.

Hay de la otra parte en la población de los españoles un monasterio de monjas de la Madre de Dios, que aunque el edificio no es señalado, en el número de monjas y en la bondad y observancia de la religión y calidad de sus personas es tan célebre

5. Francisco Cervantes de Salazar, México en 1554 y Túmulo imperial, México, Porrúa, 2000, pp. $4 \mathrm{I}-43$.

6. Ibidem, pp. 4I-57.

7. Ibidem, p. 49.

8. Cabe aquí una precisión terminológica. Tanto en el virreinato de la Nueva España como en el de Perú las instituciones religiosas de clausura para mujeres fueron designadas predominantemente conventos. Los documentos y crónicas de la época virreinal en Lima y Cuzco llaman "conventos recoletos" a las comunidades de clausura de vida común y "conventos grandes" a las de clausura de vida privada. Luis Martín, Daughters of the Conquistadores. Women of the Viceroyalty of Peru, Dallas, Southern Methodist University Press, 1989, pp. 20I-242. En algunos casos, en los textos literarios y en la documentación relacionada con las comunidades de monjas de la capital novohispana se emplea el término "monasterio" para referirse a las clausuras de monjas. Sin embargo, hacia mediados del siglo XviI la palabra convento parece predominar. A reserva de lo que futuras investigaciones aclaren al respecto, hasta el momento el término "monasterio", en el contexto de los virreinatos de Nueva Espańa y Perú, constituye un sinónimo de "convento", es decir, comunidad de monjas de clausura. 
como algunos de los nombrados de Castilla, porque en él hay muchas monjas, las más dellas hijas de hombres principales. Comienza ahora otra casa cerca desta, donde se mudarán para tener el templo y morada que conviene. ${ }^{9}$

Décadas más tarde, las religiosas también fueron un tópico destacado en la obra de Bernardo de Balbuena. En ella, los conventos de monjas y sus iglesias fueron considerados una parte significativa del paisaje urbano y un signo de la opulencia de la ciudad; al tiempo que una prueba evidente de la calidad de sus vecinos.

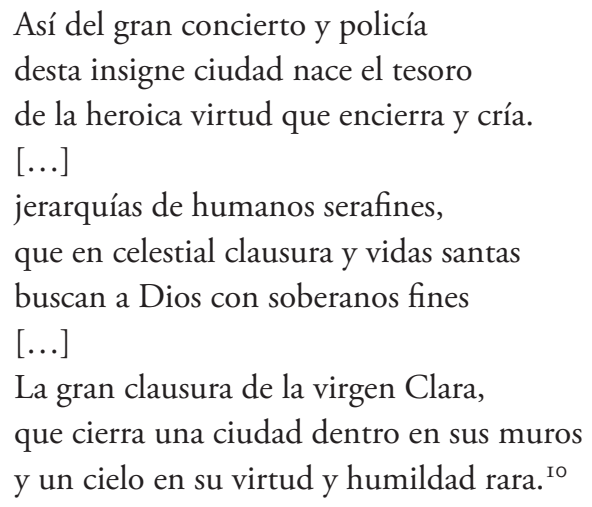

Por tanto, cada una de las diez comunidades que por entonces existía en la ciudad no fue menos digna de encomio que las poderosas órdenes masculinas. La jerarquía de sus edificios y la posición de sus moradoras funcionaron como figuras retóricas muy elocuentes para subrayar la "grandeza mexicana".

Sin embargo, la presencia reiterada de las monjas en las laudes urbanas no parece ser un rasgo exclusivo de los primeros panegiristas novohispanos. Ellas fueron un tópico recurrente cada vez que se buscó construir una imagen de las ciudades virreinales como locus de civilización y símbolo de identidad regional en distintos puntos del imperio de ultramar. Un claro ejemplo, en este sentido, fue Lima. Fundada ex novo en I535 y convertida en capital del virreinato del Perú en I543, comenzó a crecer con rapidez a partir de la década de I560, según

9. Francisco Cervantes de Salazar, Crónica de la Nueva España [ca. I557-1564], México, Porrúa, I985, pp. $32 \mathrm{I}-326$.

Io. Bernardo de Balbuena, La grandeza mexicana y compendio apologético en alabanza de la poesía [1604], México, Porrúa, 200I, pp. Io6-II2. 


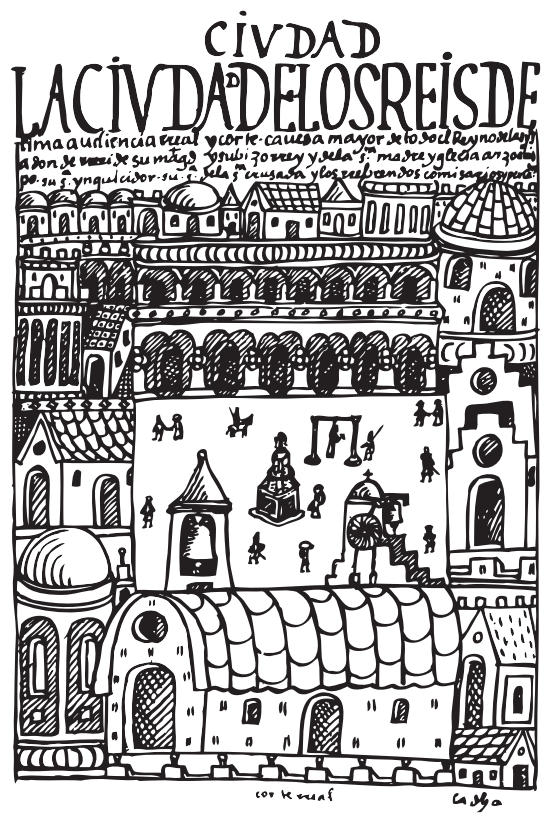

I. Felipe Guamán Poma de Ayala, Ciudad. La ciudad de los reis de Lima..., tomada de El primer nueva crónica..., op. cit. (infra n. I I), f. I03 I [1039], p. 950.

se afianzaba su función como corte virreinal y como centro administrativo, y se convertía en un enclave mercantil estratégico vinculado al puerto del Callao. $\mathrm{Si}$ bien las primeras descripciones no la destacan como una ciudad trazada con especial orden, en ella ya sobresalían sus edificios más representativos: la catedral, las parroquias, los conventos de frailes y, por supuesto, los primeros conventos de monjas. De tal modo que ya Felipe Guamán Poma de Ayala utilizó algunos tópicos tradicionales de la laudatio urbis para mostrar una imagen civilizada del Nuevo Mundo y, entre ellos, enumeró los conventos de monjas de la ciudad de Lima y los destacó como ejemplo de orden y buen gobierno (figs. I, 2 y 3). ${ }^{\text {II }}$

A lo largo del siglo XviI, el lugar de las comunidades de monjas dentro de los discursos de exaltación del orgullo cívico conservó su vigencia. Así, las descripciones de las grandes ciudades del virreinato del Perú y de la Nueva España incluyeron una mención especial a sus conventos de monjas. Por ejemplo, Antonio Vázquez de Espinosa y Agustín de Vetancurt enumeraron

I I. Felipe Guamán Poma de Ayala, El primer nueva crónica y buen gobierno [ca. 1583-1615], México, Siglo XXI, 2006, f. 482 [486], p. 450. 
2. Felipe Guamán Poma de Ayala, Buen gobierno. Avadeza maior y vicaria general deste reyno de las Yndias..., tomada de $E l$ primer nueva crónica..., op. cit. (supra n. I I), f. 482 [486], p. 450.

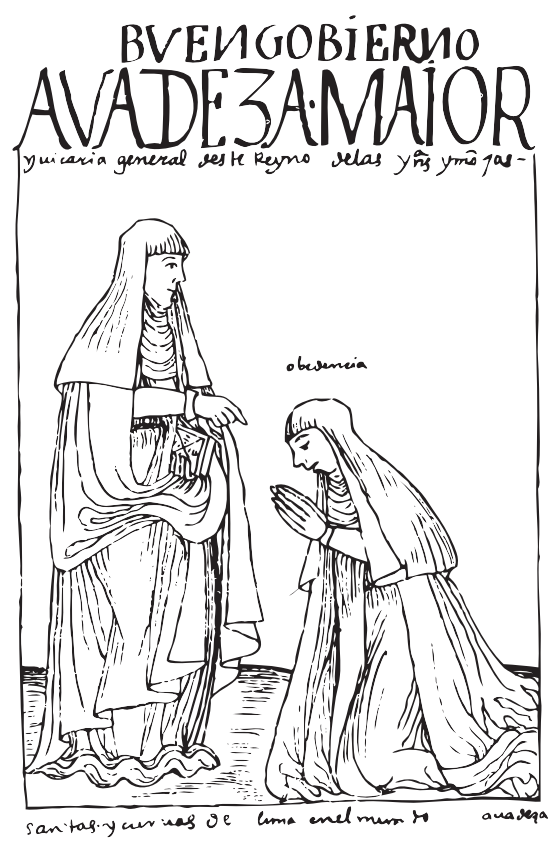

escrupulosamente los conventos de la ciudad de Lima y México, describieron los aspectos más notables de sus edificios y con detalle elogiaron la nobleza de los linajes fundadores de cada institución y la piedad religiosa de sus moradoras. ${ }^{12}$ En particular, fray Diego de Córdoba construyó una imagen de Lima a partir de una cuidadosa comparación con las grandes ciudades del Viejo Mundo. Cada una de ellas ejemplificaba las virtudes de Lima y, en conjunto, eran un espejo donde el orgullo cívico de la cultura criolla naciente encontraba un parangón.

No tiene Lima que envidiar las glorias de las ciudades antiguas, porque en ellas se reconoce la Roma santa en los templos y divino culto; la Génova soberbia en el garbo y brío de los hombres y mujeres que en ella nacen; Florencia hermosa por la apacibilidad de su temple; Milán populosa por el concurso de tantas gentes como

I2. Antonio Vázquez de Espinosa, Compendio y descripción de las Indias Occidentales [1628], Madrid, Atlas, 1969, pp. 302-303; Agustín de Vetancurt, Teatro mexicano [1697-1698], México, Porrúa, I982, ff. 4I-43. 


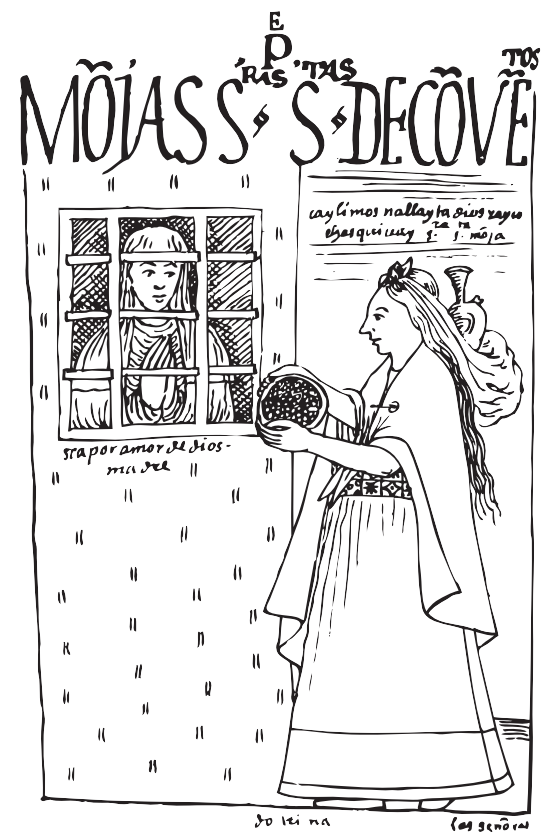

3. Felipe Guamán Poma de Ayala, Padres/ Monjas señoras santas de conventos..., tomada de El primer nueva crónica..., op. cit. (supra n. I I), f. 633 [647], p. 600.

acuden a ella; Lisboa por sus conventos de monjas, música y olores; Venecia rica por las riquezas que produce para Espańa y liberal reparte a todo el mundo; Bolonia pingüe por la abundancia del sustento; Salamanca por su florida universidad, religiones y colegios. ${ }^{13}$

Cada tópico de la laudatio urbis está representado por una ciudad emblemática, la magnificencia arquitectónica, las bondades del clima y la abundancia de sus recursos naturales, la riqueza y la prosperidad, la calidad, piedad y sabiduría de los habitantes y, no menos importantes, sus conventos de monjas.

Ahora bien, de forma paralela, el discurso de la laudatio urbis se expresó además por otros medios. Las imágenes visuales de la ciudad de México creadas durante el siglo XVII — por ejemplo las plantas y las vistas realizadas por Juan Gómez de Trasmonte en 1628 o la vista de la ciudad del reverso del Biombo de la conquista - asentaron con escrupulosidad informativa los monumentos

I3. Diego de Córdoba y Salinas, Teatro de la santa Iglesia Metropolitana de los Reyes [1650], cit. en Kagan, op. cit., p. 267. 
que encarnaron el orgullo cívico. Con igual énfasis se registraron detalles topográficos, se destacó la regularidad de la traza y la importancia de la catedral, se consignaron las parroquias, los edificios de las órdenes religiosas, y se informó con igual detalle el nombre y la ubicación de los catorce conventos de monjas (figs. 4 y 6). Asimismo, el plano de Lima publicado por Francisco de Echave y Assu puede interpretarse como una laudatio urbis visual. ${ }^{14}$ En él se incluyeron las murallas recién terminadas, se describió la regularidad de su traza y se anotaron, con exactitud, los edificios y espacios significativos de la capital: la plaza, la catedral, el palacio, la universidad, las parroquias, los conventos de frailes y - por supuesto- las comunidades de monjas. Se trata, sin duda, de una imagen - un discurso visual — que destaca los datos informativos sobre la urbs de Lima, como recurso retórico para ponderar la calidad de su civitas (fig. 7).

Es indudable que el plano de Trasmonte y la vista panorámica de la ciudad de México, así como la planta de Lima dibujada por fray Pedro Nolaso, no son rigurosamente exactos en el registro topográfico y en las características de algunos de sus edificios. Sin embargo, tampoco son pura retórica en cuanto a la documentación de la estructura urbana y arquitectónica. En los tres casos es evidente que se buscaba destacar la magnitud de ambas capitales y la envergadura de los edificios más significativos. Entre ellos y más allá de las hipérboles visuales, destacan las dimensiones de los conventos de monjas.

En especial, hacia finales del siglo XvII, junto con las crónicas y los planos, también comenzó a difundirse en la cultura virreinal un género de pintura que fusionó el tema de la ciudad — como paisaje arquitectónico- con la descripción costumbrista. Por lo general no se trató de pinturas estrictamente tomadas del "natural", sino, en lo fundamental, de la transposición visual de algunos tópicos de la laudatio urbis. ${ }^{15}$ Así, por ejemplo, la Plaza Mayor de Lima en 1680 ofrece una vista del corazón de la pujante capital. En ella se describe con detalle el escenario arquitectónico, el conjunto de la sociedad virreinal

I4. Francisco de Echave y Assu, La estrella de Lima convertida en Sol sobre sus tres coronas, Amberes, Juan Baptista Verdussen, I688. El plano, realizado por fray Pedro Nolaso, deriva de uno dibujado por el jesuita flamenco Juan Ramón Koninick, en relación con el proyecto de construcción de las murallas defensivas de la ciudad encabezado por el virrey duque de Palata (I68I-I689). Kagan, op. cit., pp. 268-270; Luis Eduardo Wuffarden, "La ciudad y sus emblemas: imágenes del criollismo en el virreinato del Perú", en Los siglos de oro en los virreinatos de América, I550-I700, Madrid, Sociedad Estatal para la Conmemoración de los Centenarios de Felipe II y Carlos V, 2000, pp. 69-7I.

I5. Ibidem, pp. 59-75. 


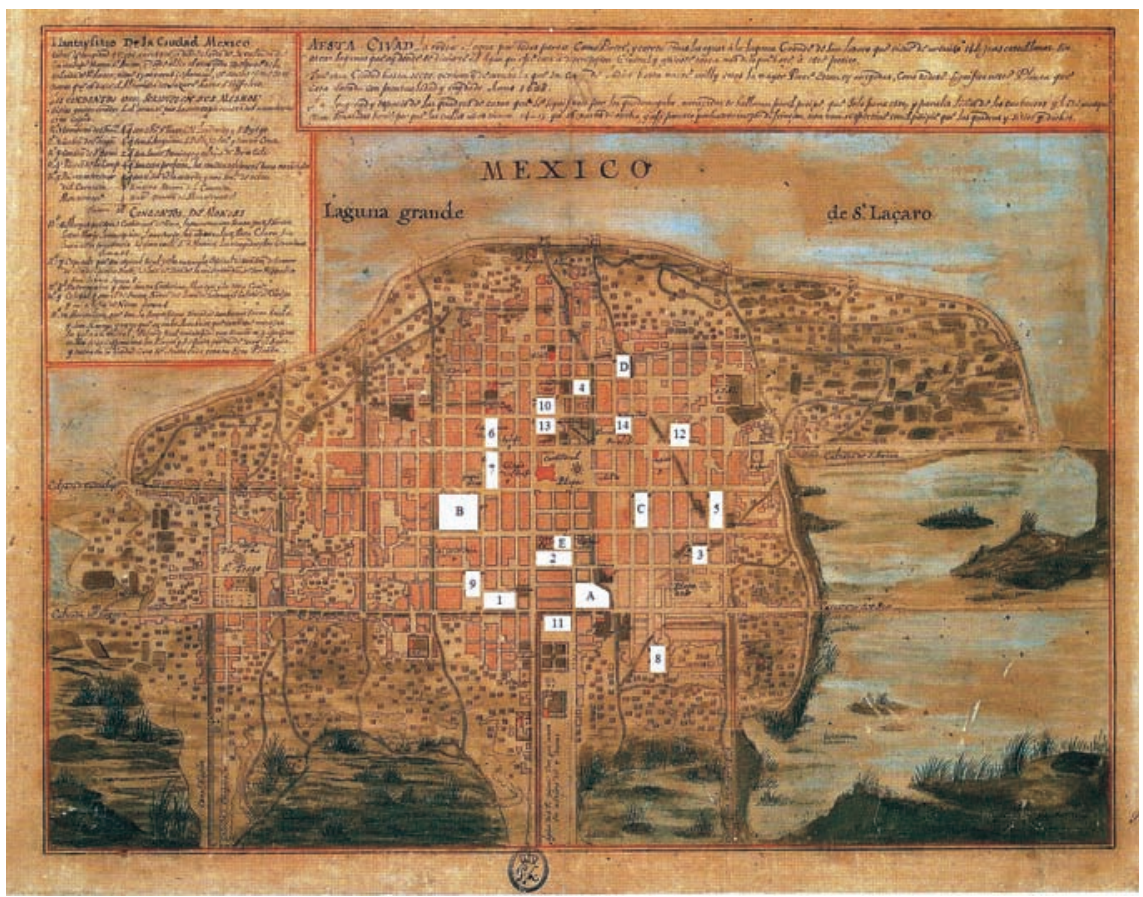

4. Luis Gómez de Trasmonte, Ciudad de México, I628, tinta y aguada, $47.2 \times 65 \mathrm{~cm}$, Florencia, Biblioteca Medicea Laurenziana.

I. La Concepción (I 540)

2. Santa Clara (I 570)

3. Regina Coeli (I 573)

4. Jesús María ( 158 I )

5. San Jerónimo (1 585 )

6. Santa Catalina (1 593 )

7. La Encarnación (I 593)

8. S. Juan de la Penitencia (I 598 )

9. San Lorenzo (I 598 )

Io. Santa Inés (I600)

I I. Santa Isabel (i6or)

I2. San José de Gracia (I6 Io)

I3. Sta. Teresa la Antigua (I6 I 5 )

I4. Recogimiento de Jesús de la Penitencia (I 572), Balvanera (1634)
A. San Francisco (I 525 - I 530 )
B. Santo Domingo (ca. I 530 )
C. San Agustín (ca. I 540)
D. La Merced
E. La Compañía de Jesús 


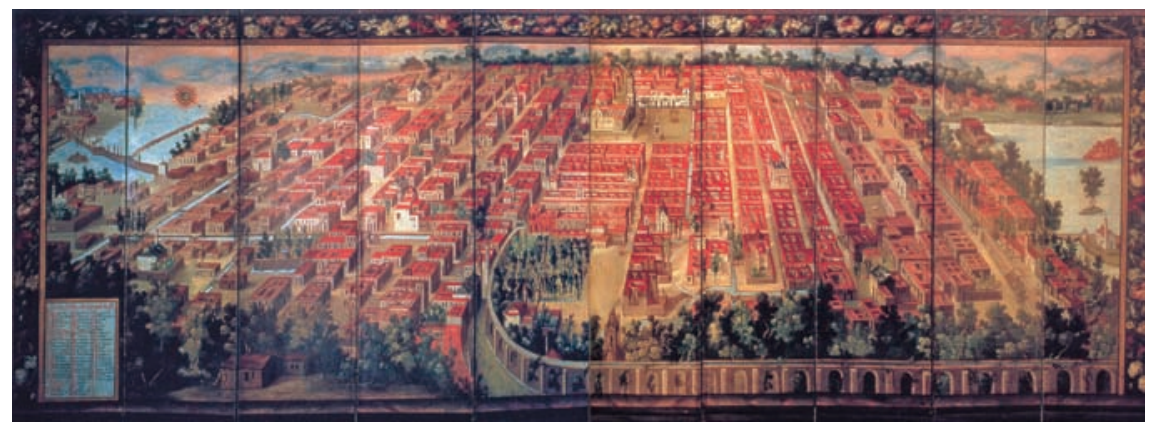

5. Anónimo, Vista de la ciudad de México, reverso del Biombo de la Conquista, siglo xvir, óleo sobre tela, 2 I $3 \times 550 \mathrm{~cm}$, México, Museo Franz Mayer.

- en cada uno de sus estamentos-, sus actividades y los productos característicos de la región. La vista hacia el oriente, desde el ayuntamiento, presenta el espacio de la plaza y los edificios que encarnaron el orden social: los palacios del virrey y del arzobispo, el sagrario y la catedral. Detrás de ellos, la silueta de la urbe se pierde en el paisaje; sin embargo, se delinearon no sólo los grandes edificios de las órdenes religiosas - el Convento de San Francisco y la Iglesia de la Compañía de Jesús-, sino también tres de los grandes conventos de monjas de la capital — Santa Clara, la Concepción y Santa Catalina. Sin duda, es una vista topográfica precisa en la identificación y posición de los edificios destacados. Al mismo tiempo, la selección de elementos debe entenderse como un recurso visual con el que se buscaba expresar el orgullo cívico, cimentado en los imponentes conjuntos conventuales de monjas no menos que en las casas de las poderosas órdenes masculinas (fig. 8).

Asimismo, dos imágenes informan del papel significativo que representaron las monjas en el contexto de la ciudad de Cuzco. Una pintura de autor desconocido, Cuzco después del terremoto de 1650, ofrece una vista panorámica de la ciudad — como urbs - y documenta su destrucción, al tiempo que muestra cómo los miembros de la comunidad — su civitas — piadosamente imploran la protección divina frente a la catástrofe. El cabildo eclesiástico, las órdenes religiosas, caballeros y damas forman parte de una procesión encabezada por la imagen conocida bajo la advocación de "Nuestro Señor de los Temblores". En igual medida, aparecen grupos de indios orando. Sin embargo, nada más significativo que las monjas de Santa Catalina, quienes han abandonado su 


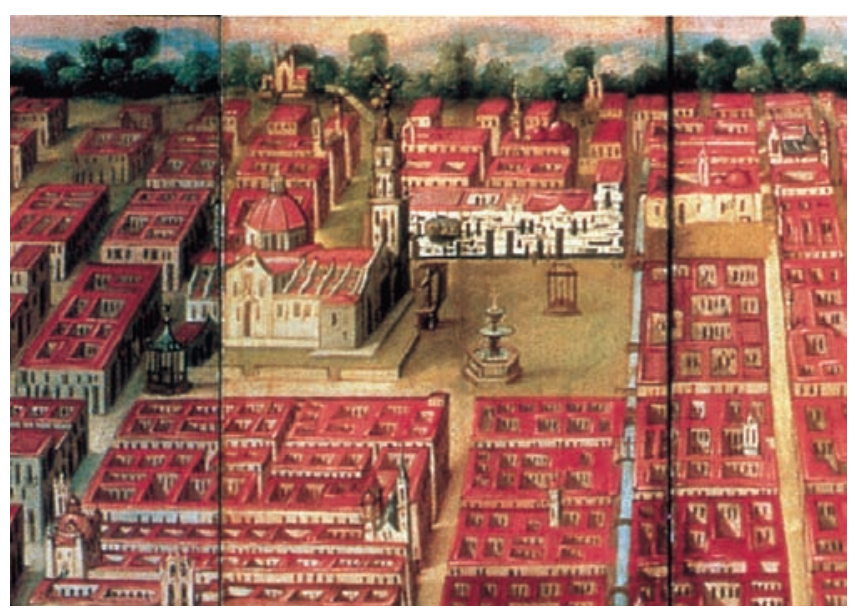

a)

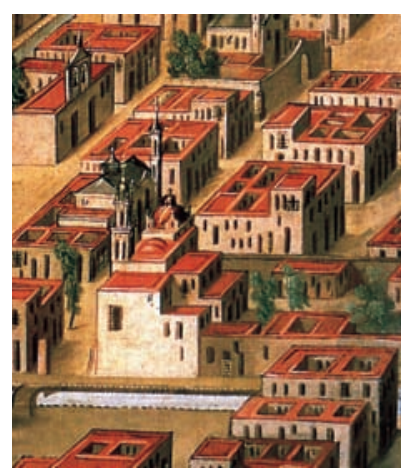

b)

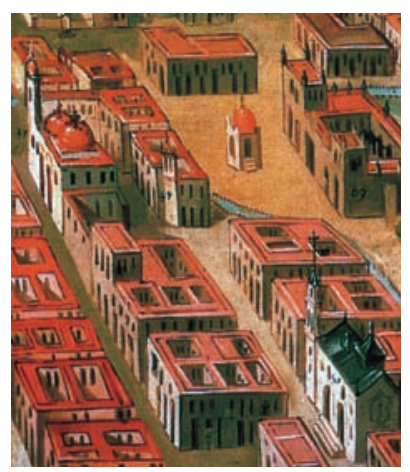

c)

6. Detalles de la Vista de la ciudad de México; a) la Plaza Mayor, la Catedral, el Palacio y el Convento de Jesús María; b) conventos de la Concepción y San Lorenzo; c) conventos de San Jerónimo y Regina Coeli.

convento tras el derrumbe de parte del edifico y rezan en medio de la calle. ${ }^{16}$ Sin duda, el terrible acontecimiento dio al artista la posibilidad de recordar visualmente un hecho excepcional: las monjas orando fuera de la clausura. Al mismo tiempo, y de forma elocuente, enunció en una imagen algo que de 


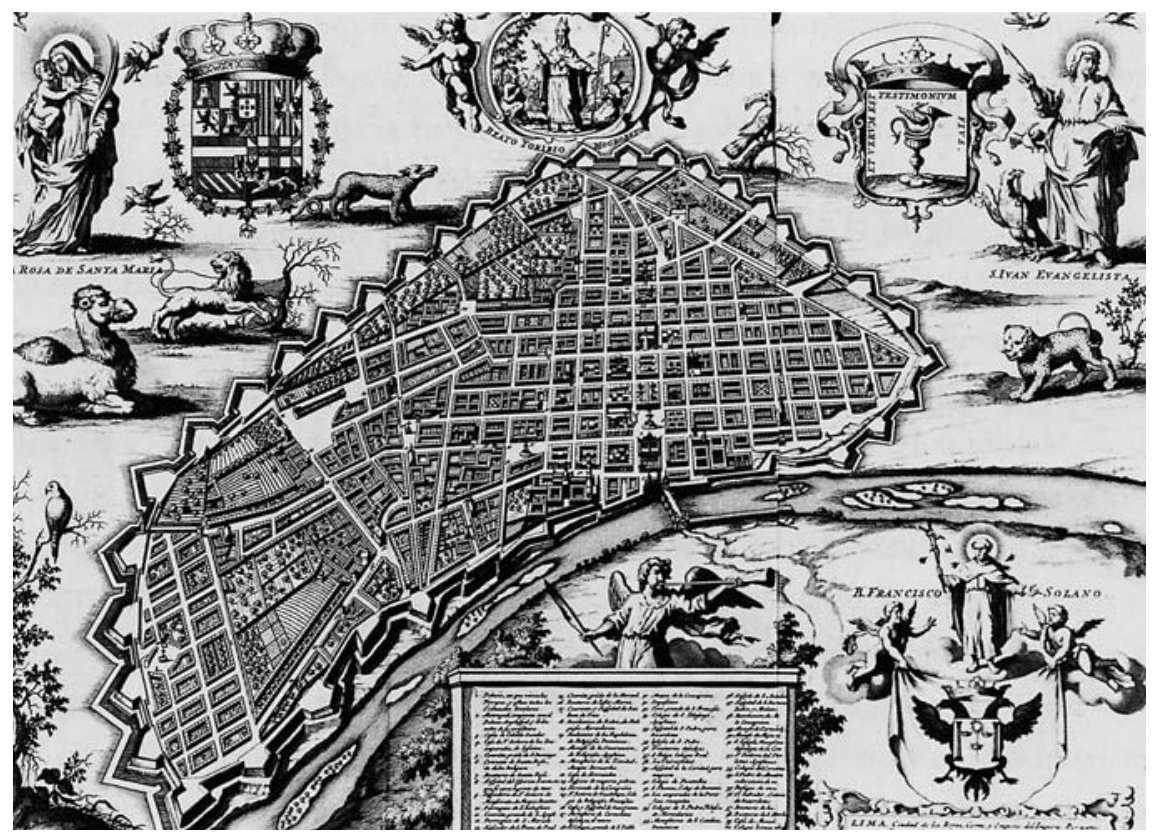

7. Fray Pedro Nolaso, Planta de la ciudad de Lima, tomada de De Echave y Assu, op. cit. (supra n. I4).

ningún modo era extraño ni excepcional: el hecho de que las monjas, aunque ocultas, formaron parte fundamental de la civitas virreinal y estuvieron siempre presentes detrás de los muros de las clausuras. Precisamente, la imagen hace tangible a aquel grupo de vírgenes invisibles que con sus rezos intercedían ante Dios e imploraban la protección de sus vecinos (fig. 9). Asimismo, la serie de lienzos que representa la procesión del Corpus, proveniente de la Parroquia de Santa Ana de la ciudad de Cuzco, revela una imagen de la urbs y la civitas de la gran ciudad. La serie es un retrato del paisaje urbano y de sus habitantes. En cada cuadro las calles y las iglesias de Cuzco son el escenario de la procesión de los distintos miembros de la sociedad y sus corporaciones claramente reconocibles. Resulta significativo que el primer lienzo de la serie —en donde se representa el principio de la procesión y en el que se ve al obispo Mollinedo portando la hostia bajo el palio- incluya, en primer término, el retrato de una monja. Aunque no ha sido identificada, no resulta aventurado 


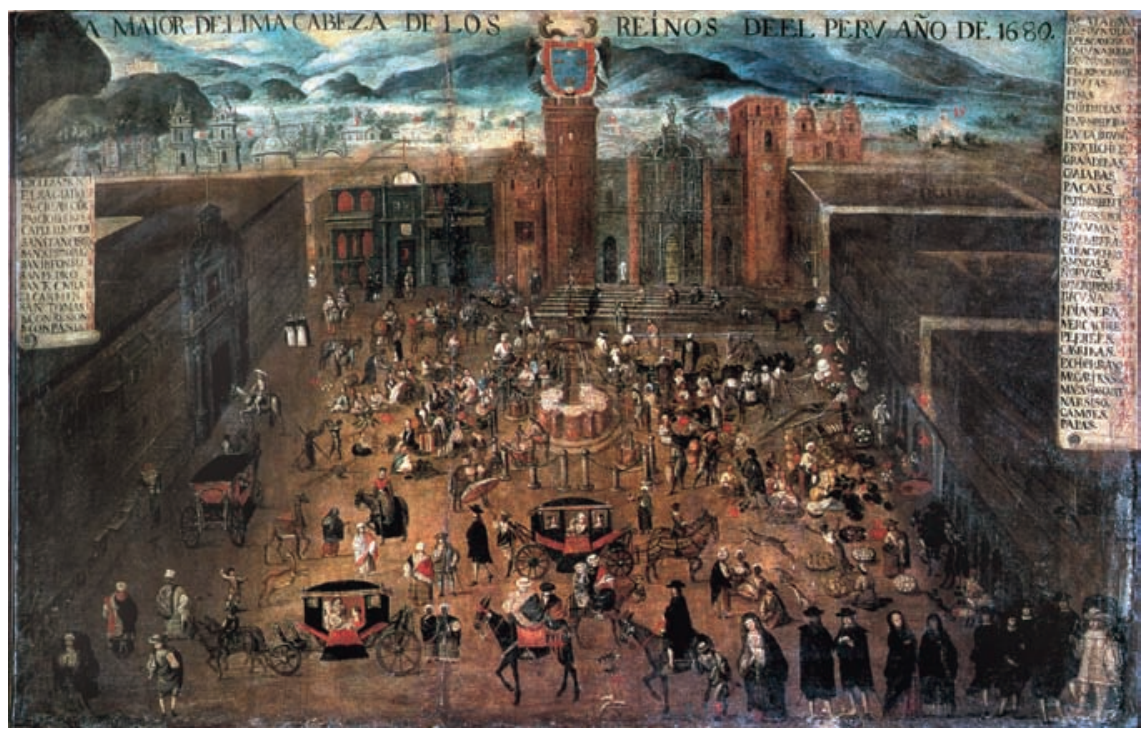

a)

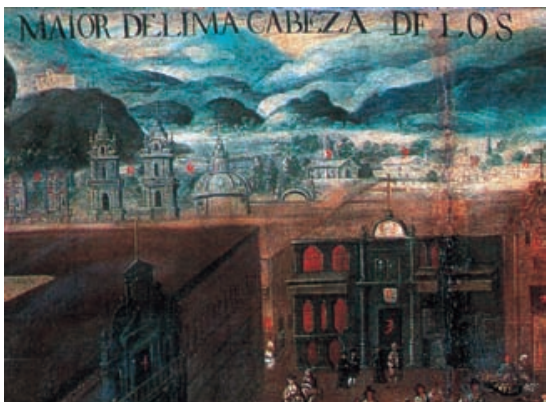

b)

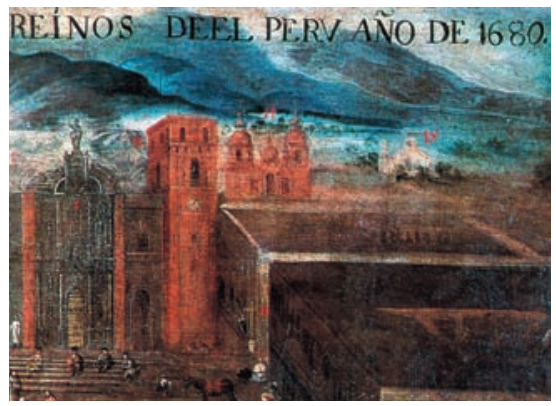

c)

8. Anónimo, Plaza Mayor de Lima en I680, óleo sobre tela. Colección particular, Gran Bretaña, a) detalle del Convento de San Francisco (6) y del Convento de Santa Clara (Io); b) detalle del Convento de la Concepción (I 3), de la Compañía de Jesús (I4) y del Convento de Santa Catalina ( 5 ). 


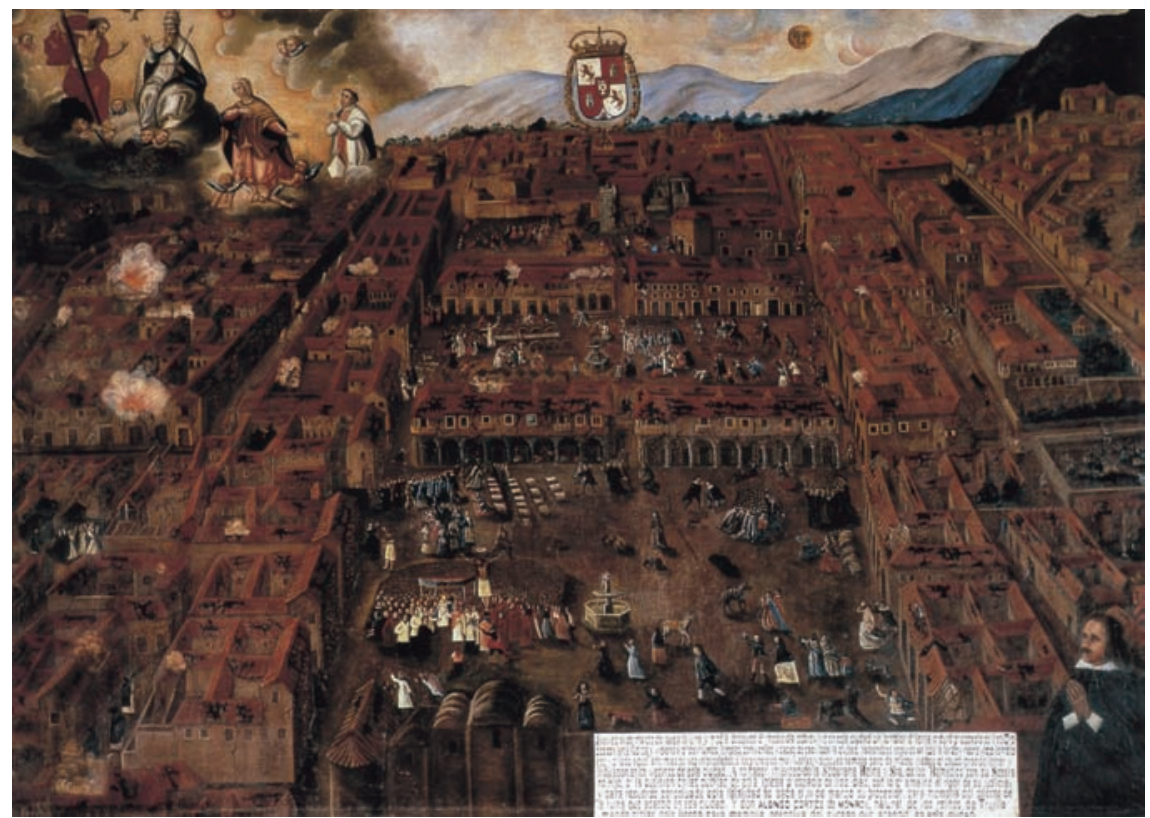

9. Anónimo, Cuzco después del terremoto de I650, ca. I650-1660, Catedral de Cuzco.

conjeturar que la religiosa fuera quien pagó el lienzo. Obviamente, las monjas no asistían a los acontecimientos públicos de manera directa. El patrocinio de una pintura fue una forma de estar presente en la procesión de Corpus, un acto cívico de la mayor relevancia. Al mismo tiempo, el hecho de que se hiciera retratar en ella refleja la importancia de su lugar social (fig. Io).

En síntesis, los conventos de monjas, sus iglesias y sus moradoras fueron considerados una parte significativa del mundo urbano y, al mismo tiempo, un signo de la opulencia, la nobleza y la piedad de los ciudadanos. De esta forma, la presencia y la importancia de las monjas resulta insoslayable. Sin embargo, pese al espacio destacado que las monjas tuvieron dentro del mundo urbano y al lugar que ocuparon en la composición de la fisonomía de la ciudad, poca atención se ha puesto en la relevancia que para sus contemporáneos tuvieron aquellas comunidades. La historia del arte apenas ha comenzado a dar cuenta de ellas, tal vez detenida ante un concepto de clausura, castidad, vida comunitaria y pobreza demasiado atado al presente, o quizá condicionada por los prejuicios de los diferentes paradigmas científicos. En general, la his- 
toria del arte ha ignorado o, en el mejor de los casos, apenas ha comenzado a considerar un conjunto de obras arquitectónicas que en su época tuvieron un valor y un significado que debe ser redescubierto.

\section{Los conventos de monjas y el espacio urbano}

Ahora bien, la importancia de las monjas dentro de la cultura urbana, en uno y otro punto del continente, no se deduce sólo a partir de su presencia constante en los diferentes discursos que conformaron las expresiones del orgullo cívico durante el periodo virreinal. El análisis de la estructura de estos edificios permite vislumbrar inmediatamente la enorme gravitación que tuvieron dentro del espacio social y urbano. Desde diversos aspectos, lejos de ser estructuras aisladas — ciudades cerradas dentro de la gran ciudad-, mantuvieron siempre una relación estrecha, dinámica y abierta con el mundo urbano. Los grandes conjuntos conventuales, así como las riquezas de sus templos, dieron una presencia pública constante a aquel grupo de mujeres invisibles que, desde un riguroso aislamiento, hacían sentir su presencia, entre otros recursos, por medio del esplendor arquitectónico de sus edificios.

Una de las características más llamativas de las grandes ciudades virreinales fue el alto número de conventos de monjas y, más aún, la rapidez con la que surgieron, uno tras otro, en especial desde mediados del siglo Xvi y durante el XVII. ${ }^{17}$ A sólo 50 años de su fundación, la ciudad de México ya contaba con cuatro establecimientos religiosos para mujeres, dos de ellos conventos de clausura. ${ }^{18}$ Entre 1530 y I600, se crearon doce instituciones femeninas, dos de las

17. Por ejemplo, la ciudad de México tuvo 2 I conventos de monjas, Puebla — la segunda ciudad del virreinato- once y Querétaro tres. Cfr. María Concepción Amerlinck y Manuel Ramos Medina, Conventos de monjas. Fundaciones en el México virreinal, México, Condumex-Centro de Estudios de Historia de México, I995, pp. 3 I-I 47, I53-I93 y 205-213. En igual medida, para la historia de los conventos de monjas novohispanos resulta importante tener en cuenta la obra pionera de Josefina Muriel (Conventos de monjas en la Nueva España [1946], México, Jus, 1995). En Lima se fundaron trece conventos y Cuzco contó con otros tres. También hubo conventos en Arequipa, Potosí, La Plata, Santiago de Chile, Córdoba y Buenos Aires y, al igual que en Nueva España, aun en algunas villas más pequeñas. Martín, op. cit., pp. I7 I-200.

I8. Hacia esta fecha había en la ciudad de México dos comunidades de monjas de clausura, el Convento de la Concepción y el de Santa Clara; además del recogimiento de Jesús de la Penitencia - que en I634 se convertiría en el Convento de Nuestra Señora de Balvanera- y el beaterio de Santa Lucía - que en 1573 se transformó en el Convento de Regina Coeli. Cristina Ratto, "El 
Io. Anónimo, El obispo Mollinedo llevando la Custodia, Serie Procesión de Corpus Christi, ca. I680, Cuzco, Museo de Arte Religioso.

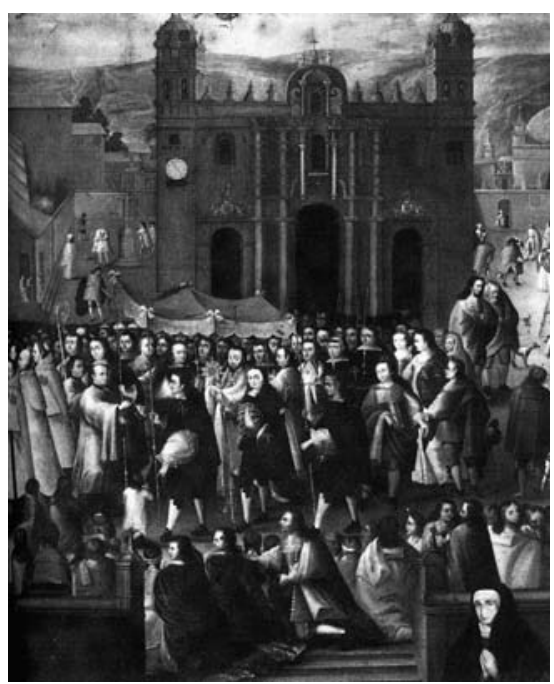

cuales permanecieron como beaterios hasta las primeras décadas del siglo XVII. Si se toma en cuenta que a finales del siglo XVIII en la capital del virreinato hubo 2 I conventos de monjas, resulta entonces que la mitad de ellos se fundó durante los primeros 70 años. En igual medida sorprende no sólo la gran cantidad, sino, sobre todo, sus dimensiones. La importancia de los conventos de monjas dentro de las estructuras urbanas se hace evidente sólo con reparar en la extensa superficie que ocuparon. En la capital novohispana, el Convento de la Concepción ocupó $26752 \mathrm{~m}^{2}$, el de Jesús María I2 I22, el de San Jerónimo I 2 540; incluso los más pequeños, como los de Santa Inés y San Bernardo, alcanzaron los 7942 y $7106 \mathrm{~m}^{2}$, respectivamente; resulta claro entonces que manzanas completas fueron ocupadas por las estructuras conventuales. ${ }^{\text {I9 }}$ Este aspecto también es evidente en los planos y vistas del siglo XVII. Si en buena medida la traza de la ciudad de México cobró forma a través de los edificios levantados por las órdenes religiosas masculinas, un papel similar tuvieron los conventos de monjas. La capital virreinal creció rápidamente conteniendo estructuras que, en la mayoría de los casos, se extendieron casi al mismo

convento de San Jerónimo de la ciudad de México. Tipos arquitectónicos y espacios femeninos en los siglos XVII y XVIII", tesis de doctorado en Historia del Arte, México, Universidad Nacional Autónoma de México-Facultad de Filosofía y Letras, 2007, pp. I89-I9o y gráfico 8, pp. 434-437. 19. Ibidem, gráfico 20, p. 445 . 
ritmo. Esos enormes conjuntos absorbieron superficies considerables de suelo dentro de la traza; señalaron calles, dieron origen a espacios públicos — como plazas o fuentes- y definieron con su presencia vecindarios completos.

Otro tanto sucedió en Lima. La capital peruana llegó a tener un total de trece conventos de clausura. Los primeros seis se fundaron entre mediados del siglo XVI y las primeras décadas del Xvir. En particular, sobresale la extensa superficie que ocuparon. Al igual que los de la capital novohispana, se distribuyeron dentro de la traza y llegaron a invadir alrededor de un quinto de la superficie de Lima. ${ }^{20}$ El Convento de la Encarnación —el primero del Virreinato del Perúse fundó en 156r. De acuerdo con el testimonio de Bernabé Cobo, "En grandeza de sitio hace ventaja este monasterio a todos los otros de monjas de esta ciudad, porque coge una isla de dos cuadras y media en largo, dentro de la cual es tanta la cantidad de edificios que hay, que parece un pueblo formado". ${ }^{21}$

En I573, sólo diez años más tarde, surgió el Convento de la Concepción, que ocupó una cuadra y media. ${ }^{22}$ La Santísima Trinidad —ubicado al igual que la Concepción a sólo tres calles de la Plaza Mayor y, de acuerdo con Cobo, en la mejor zona de la ciudad — rápidamente había adquirido e incorporado a la clausura todas las casas de la cuadra. ${ }^{23}$ Un poco más grandes fueron los conventos de Santa Clara y Santa Catalina, cada uno de ellos alcanzó una superficie de más de una manzana y media. ${ }^{24}$ Similares dimensiones tuvieron los dos conventos grandes de Cuzco: Santa Clara ocupó una extensa manzana junto al Convento de San Francisco y Santa Catalina se levantó en un vasto predio a dos calles de la catedral. ${ }^{25}$ Igualmente dilatado fue el Convento de Santa Clara de Arequipa, cuyo crecimiento entre los siglos XVII y XVIII determinó una extensión de 20426 $\mathrm{m}^{2}$, casi tan grande como el de la Concepción de México. ${ }^{26}$

20. Martín, op. cit., p. 172.

2I. Bernabé Cobo, Obras (Historia del Nuevo Mundo). Biblioteca de Autores Españoles [I639], Madrid, Atlas, I964, t. 92, p. 429.

22. Ibidem, p. $43 \mathrm{I}$.

23. Ibidem, pp. 43I-432.

24. Idem.

25. Cuzco. Reconstruction of the Town and Restoration of its Monuments, París, Organización de las Naciones Unidas para la Educación, la Ciencia y la Cultura (Unesco), I952, pp. I3 y I6-I8; Kathryn Burns, Colonial Habits. Convents and the Spiritual Economy of Cuzco, Peru, Durham/ Londres, Duke University, I999, pp. I05-II2.

26. Ramón María Serrera y Luisa Figallo, "El desarrollo arquitectónico y urbano de un convento-ciudad en el Perú colonial: el monasterio de la Encarnación de Lima”, en Groupe In- 
De este modo, los conjuntos conventuales crecieron dentro de las grandes ciudades virreinales y sustrajeron con rapidez vastas porciones del espacio habitable. Tan es así que, en las ciudades virreinales de cierta importancia, ya desde el comienzo del siglo XviI, resultaba difícil caminar sin toparse con los muros de las clausuras de monjas y con sus iglesias. En consecuencia, los conventos de monjas, insertos de manera vital dentro de la ciudad, también fueron en sí mismos "pequeñas ciudades". Ciudades físicamente cerradas, pero profundamente unidas al espacio urbano.

\section{Las ciudades dentro de la gran ciudad desde el interior}

Resulta fácil comprobar cómo la disposición y la historia constructiva de los conjuntos conventuales los asemeja, en determinados aspectos, a una estructura de tipo urbana. Más allá de diferencias particulares, es posible observar una disposición general y una historia constructiva similares presentes en estos edificios, tanto en el virreinato de Nueva España como en el de Perú. Algunos ejemplos pueden citarse en las ciudades de México, Lima, Cuzco y Arequipa.

El Convento de San Jerónimo de la ciudad de México - fundado en I585-, lejos de responder a una traza, fue conformándose a medida que su comunidad crecía. Su estructura presenta una disposición rectangular en la que es posible reconocer dos sectores formal y funcionalmente diferenciados: el núcleo conventual y la zona de celdas. El núcleo conventual, ubicado sobre el perímetro norte-oriente de la manzana, reunió el templo y los espacios de uso comunitario - las porterías, el torno, los locutorios y, probablemente, la sala de labor, el dormitorio común y el noviciado. Este sector del edificio tomó forma a partir de la adaptación de parte de la extensa vivienda suburbana adquirida por los fundadores y en las sucesivas renovaciones realizadas entre finales del siglo XVI y durante el xviI, conservando sus rasgos fundamentales desde principios del siglo XVIII hasta mediados del XIX. En consecuencia, el núcleo conventual y la estrecha franja del perímetro poniente — destinada a los servicios y a una portería secundaria - ocuparon aproximadamente una cuarta parte de la superficie total. La zona de celdas, formada mediante la adición constante de unidades

terdisciplinaire de Recherche et de Documentation sur l'Amérique Latine, Structures et cultures des sociétés ibéro-américaines. Colloque International en Hommage au Professeur François Chevalier (1988), París, Éditions du Centre National de la Recherche Scientifique, I990, p. 299. 


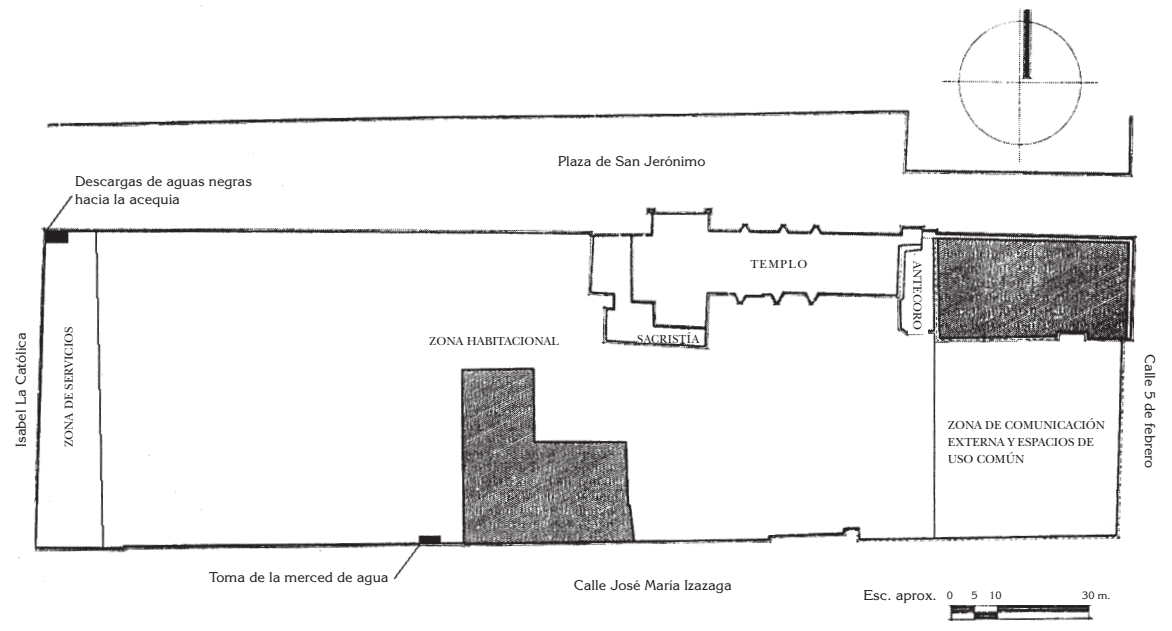

I I. Planta del Convento de San Jerónimo de la ciudad de México con la distribución de funciones. A partir del plano publicado por Daniel Juárez Cossío, El convento de San Jerónimo. Un ejemplo de arqueología histórica, México, Instituto Nacional de Antropología e Historia, I989.

habitacionales de diferentes tamaños, se extendió sobre el sector centro-poniente del conjunto y ocupó alrededor de tres cuartas partes de la manzana. La composición intrincada y densa fue consecuencia de un espacio que sufrió constantes modificaciones desde finales del siglo XVI hasta mediados del XIX. Sin duda, las características formales de ambas áreas y su pervivencia dejan ver la importancia indiscutible que los espacios privados — las celdas - tuvieron en la vida conventual. La distribución del conjunto revela que la vida en común ocupó un espacio menor. En síntesis, resulta claro que, pese a los cambios y modificaciones parciales, el núcleo conventual y la zona de celdas se mantuvieron como sectores claramente diferenciados (figs. I I y I2). ${ }^{27}$

Ahora bien, San Jerónimo no fue el único convento con esta disposición. Otros conjuntos de la ciudad de México presentaron una historia constructiva y un ordenamiento similares. Por ejemplo, el Convento de Jesús María — fundado también a finales del siglo xvI — tuvo una historia constructiva 


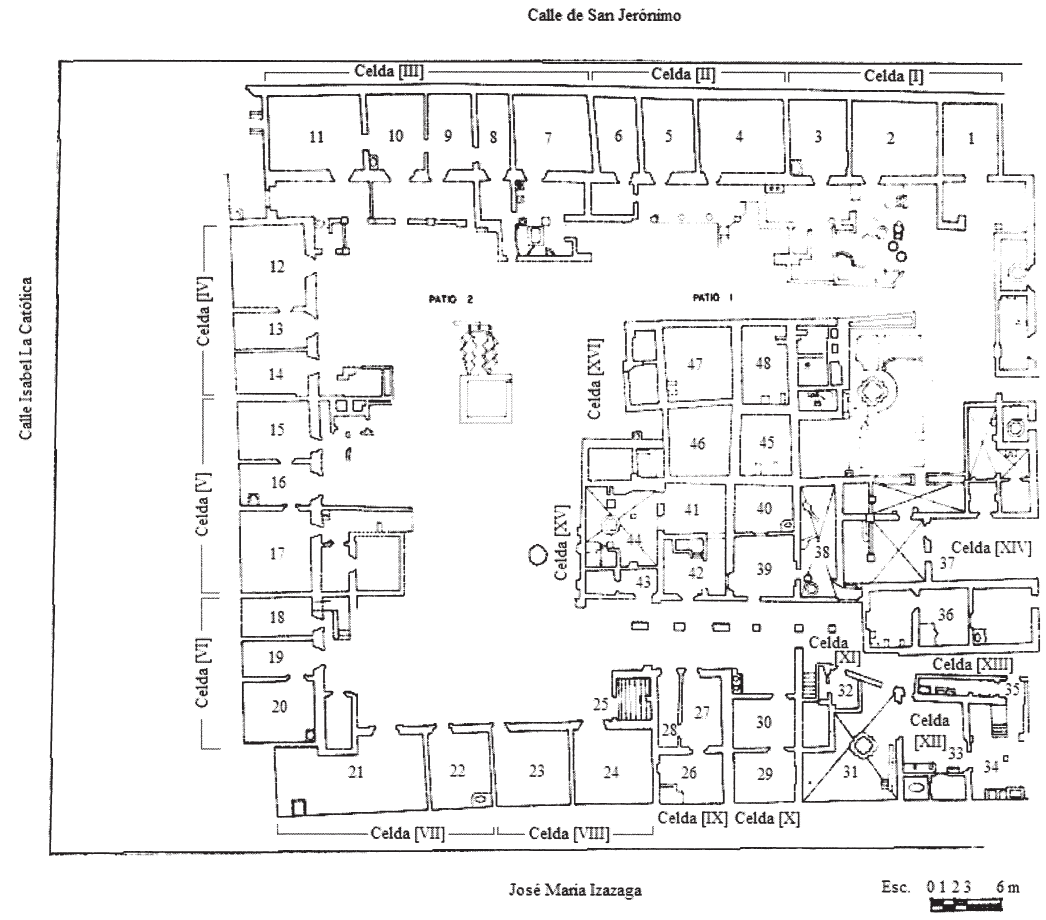

I 2. Planta del patio poniente del Convento de San Jerónimo de la ciudad de México (entre finales del siglo xvir y xvinI), con la identificación de las celdas. A partir del plano publicado por Daniel Juárez Cossío, El convento de San Jerónimo. Un ejemplo de arqueología histórica, México, Instituto Nacional de Antropología e Historia, I989.

semejante a la de San Jerónimo y su estructura puede clasificarse dentro del mismo tipo. ${ }^{28}$ El edificio nació a partir de una propiedad urbana de considerables dimensiones ubicada en la esquina de la calle "por donde corría la acequia real" y la que "iba de la plazuela de San Gregorio al colegio de San Pablo" (actualmente las calles de Jesús María y Corregidora). En este punto de la manzana, tras las primeras adaptaciones realizadas en la gran residencia,

28. Nuria Salazar Simarro ha reconstruido, a partir de una rigurosa investigación documental, la historia constructiva del Convento de Jesús María. Tal estudio brinda una idea precisa constructiva del conjunto y la distribución de los espacios ("El convento de Jesús María de la ciudad de México. Historia artística I577-I860”, tesis de licenciatura, México, Universidad Iberoamericana, I986). 
se concentraron las áreas de comunicación externa, los espacios destinados a la vida en común y el templo. En consecuencia, el lado sur y el oriente conformaron el perímetro asignado a la comunicación externa y en esta zona se concentraron los espacios destinados a la vida comunitaria. A espaldas de esta estructura se distribuyeron de forma abigarrada las celdas, tal y como sucedió en San Jerónimo.

Sin embargo, San Jerónimo se fundó en una finca suburbana ubicada en el extremo sur de la traza - la zona menos desarrollada de la ciudad a finales del siglo Xvi. ${ }^{29}$ Por el contrario, Jesús María se localizó a dos calles de la Plaza Mayor, detrás del Palacio Virreinal y la Audiencia; por tanto, en un sector privilegiado, casi céntrico y, sobre todo, ya densamente edificado. Por consiguiente, a diferencia de San Jerónimo - cuya superficie comprendió la manzana completa desde el momento de su fundación y en donde las celdas dominaron con el correr del tiempo todo el espacio disponible-, el conjunto conventual de Jesús María creció mediante la adquisición de las casas colindantes con este primer núcleo. En tanto que la comunidad aumentaba - y con ello la falta de espacio para la construcción de celdas se convertía en un problema-, las familias de las monjas adquirieron las propiedades vecinas al convento con el fin de levantar celdas.

Un proceso similar puede reconocerse en la ciudad de Cuzco. El Convento de Santa Clara - fundado en I55 I- nació a partir de una vivienda urbana comprada por el cabildo de la ciudad. El Convento de Santa Catalina - la segunda institución de clausura para mujeres en Cuzco- surgió cuando la comunidad de Nuestra Señora de los Remedios de la ciudad de Arequipa decidió trasladarse después de la erupción volcánica de 1600 y la subsiguiente serie de terremotos. Las religiosas de la nueva comunidad de Santa Catalina se establecieron en un espacio urbano con un elocuente sentido simbólico para la antigua capital del Imperio Inca. El convento fue construido sobre el acllahuasi, la casa de las "vírgenes elegidas del sol". ${ }^{\circ 0}$ Así, las "vírgenes elegidas de Cristo" se apropiaron de un espacio prehispánico para instaurar una nueva tradición. Resulta importante destacar que, a otro nivel, un proceso equivalente se produjo en México cuando primero Juan de Torquemada y más tarde Carlos de

29. De acuerdo con la escritura de venta de la propiedad, fechada en la ciudad de México el Io de mayo de 1584, Isabel y Juan de Guevara — los patronos fundadores de la comunidad- adquirieron la finca que ocupaba la manzana completa. Ratto, op. cit., pp. 72-73, y Documento I, pp. 527-53I.

30. Burns, op. cit., pp. 82-90. 
Sigüenza y Góngora se refirieron a las "vestales mexicas" que servían en los templos, reinterpretando el sentido de la virginidad en el mundo prehispánico. ${ }^{\text {I }}$

Santa Clara y Santa Catalina, al igual que los conventos de la ciudad de México, se afianzaron y crecieron de manera vertiginosa durante el siglo xvir. En consecuencia, sus edificios cobraron forma en la medida que sus comunidades se desarrollaron demográfica y económicamente. En I655, sólo cinco años después del terremoto devastador, la comunidad de Santa Clara comenzó a construir un claustro nuevo que comportó una inversión significativa. Durante los mismos años, las monjas de Santa Catalina, cuyo claustro había sido destruido casi por completo, no sólo comenzaron a reconstruir el edificio sino que aumentaron su superficie, al adquirir y agregar dentro de la clausura varias calles y casas adyacentes. ${ }^{32}$

Aunque hay abundante información documental sobre el Convento de la Encarnación de Lima —el de mayor superficie y el más densamente poblado de la capital—, ${ }^{33}$ poco se sabe acerca de su estructura. El conjunto fue demolido a finales del siglo XIX, cuando se emprendió una reforma sustancial que afectó el casco antiguo de la ciudad. ${ }^{34}$ Sin embargo, los testimonios de cronistas como Bernabé Cobo y Antonio Vázquez de Espinosa —entre otros—, 35 así como las vistas axonométricas del conjunto en los planos del siglo XvII, revelan algunas características generales de esta estructura. Puede conjeturarse que se trató de un vasto edificio conformado por un núcleo que concentró el templo y las áreas de uso común y una intrincada trama de celdas que hacían de él un "pueblo formado" — tal y como lo caracterizó Cobo. ${ }^{36}$ Probablemente el núcleo conventual se concentró en uno de los extremos del predio - en torno al templo- , en tanto que las celdas se extendieron hacia el otro y cubrieron todo el espacio disponible. Tal fue el crecimiento de la estructura verdaderamente urbana del conjunto que, a mediados del siglo XVII, llegó in-

31. Juan de Torquemada, Monarquía indiana [1615], México, Universidad Nacional Autónoma de México, 1976, vol. 3, lib. IX, caps. XIV y XV, pp. 276-285; Carlos de Sigüenza y Góngora, Parayso occidental [1684], México, Universidad Nacional Autónoma de México/Condumex-Centro de Estudios de Historia de México, I995, ff. I-5.

32. Burns, op. cit., pp. I06-107.

33. De acuerdo con el testimonio de Bernabé Cobo, la Encarnación ocupó más de dos cuadras y tenía, a principios del siglo XVII, una población total de 700 personas - 300 monjas, novicias y donadas, y 400 criadas y esclavas. Cobo, op. cit., p. 429; Martín, op. cit., pp. I76-192.

34. Serrera y Figallo, op. cit., p. 30 I.

35. Cobo, op. cit., pp. 429-434; Vázquez de Espinosa, op. cit., pp. 302-303.

36. Cfr. supra n. 2 I. 
cluso a contener un eremitorio dentro de ella. De acuerdo con el testimonio del cronista agustino Bernardo de Torres, este espacio de retiro ocupó una superficie de $70 \times 35$ varas $(58.5 \times 29.26 \mathrm{~m})$ —aproximadamente $\mathrm{I} 700 \mathrm{~m}^{2}$. Se llegaba a él por la calle principal del convento y estaba cercado por un muro de adobe para preservar su aislamiento - de este modo se le ponía a salvo de los "ojos que iban y venían por la transitada calle" conventual. ${ }^{37}$ En su interior contenía un santuario con capilla principal de $22 \times$ Io varas ( $18.4 \times 8.36$ $\mathrm{m})$, rodeado por catorce pequeńas capillas con dos puertas, una orientada hacia el santuario y otra hacia el exterior. ${ }^{38}$ Destinado al retiro de las monjas, este espacio — cuya advocación era la Santa Cruz de Jerusalén- se dedicó en I649. La construcción del recinto aislado dentro de la clausura respondió a la necesidad de crear un lugar de retiro para aquellas monjas que desearan llevar una vida religiosa de mayor rigor y recogimiento, al margen del trajín de una comunidad de vida particular. De este modo, en cierta medida, el enorme conjunto conventual fue capaz de contener dos formas de vida religiosa.

Algo similar sucedió en el Convento de Santa Catalina. Fundado en I622, se edificó también de acuerdo con el testimonio de Bernabé Cobo,

en una huerta, que se compró en nueve mil pesos, al cabo de la ciudad, en términos de la parroquia de Santa Ana, en la cual parroquia caen también los conventos de las Descalzas y de Santa Clara. Tiene de sitio más de dos cuadras, quedó inclusa dentro de él una devota ermita de Nuestra Seńora de Loreto, que pocos ańos antes se había hecho, al modelo y medida de su original la casa de Loreto de Italia. ${ }^{39}$

De esta forma, la comunidad se había adueñado de un espacio de devoción pública. Al igual que el Convento de la Encarnación, su estructura estaba formada por una extensa trama de celdas y su tamaño y distribución remedaba, en tal medida, a una ciudad que podía contener espacios de devoción y recogimiento dentro de una estructura cuya función primordial, en teoría, era la reclusión religiosa.

Probablemente, el ejemplo mejor conservado de este tipo de conventos en el Virreinato del Perú sea Santa Catalina de Arequipa. En él es posible recono-

37. Serrera y Figallo, op. cit., p. 309; Antonio de la Calancha y Bernardo de Torres, Crónicas agustinianas del Perú [1637], Manuel Merino (ed.), Madrid, Consejo Superior de Investigaciones Científicas, I972, vol. II, pp. 748-753.

38. Idem.

39. Cobo, op. cit., p. 434. 
cer con claridad un núcleo conventual destinado a la vida en comunidad —-formado por templo, portería, locutorios y noviciado, entre otros- y la extensa zona habitacional ocupada por las celdas que se extendían sobre las tres cuartas partes de la superficie total del conjunto. De esta manera, la distribución del espacio en Santa Catalina de Arequipa presenta una proporción muy similar a la del Convento de San Jerónimo en la ciudad de México. En igual medida, todavía se observa la intrincada red de calles y callejuelas que permitían circular por el conjunto, así como el ordenamiento de plazas, huertas y jardines.

En consecuencia, a partir de los datos generales que se tienen sobre el proceso constructivo de estos conventos, es fácil reconocer que respondieron a un tipo de edificio similar al de los conventos novohispanos: una estructura compuesta por un núcleo, que concentró las áreas de uso comunitario, y una zona habitacional, destinada a las celdas. Sin duda, tanto en la ciudad de México como en Cuzco, Lima y Arequipa, el rasgo urbano característico de los conjuntos conventuales es la presencia de extensas superficies ocupadas por una densa trama de celdas.

Tanto en el Virreinato de Nueva España como en el de Perú, ya hacia mediados del siglo XVII, la costumbre de que las monjas habitaran de manera privada en celdas se encontraba plenamente afianzada. Cuando se utiliza el término "celda", en referencia a los conventos de vida particular — tal y como se los conocía en Nueva España - o conventos grandes — como se les designaba en el Virreinato del Perú-, se alude a una verdadera estructura habitacional. Las celdas fueron en realidad casas, de distintas dimensiones y comodidades, aglutinadas detrás de los muros de las clausuras..$^{\circ}$ En ellas las monjas pasaban buena parte del tiempo, y en ellas transcurrían sus vidas, fuera de sus obligaciones religiosas. Es en este sentido que las zonas habitacionales de los conventos de San Jerónimo y Jesús María, de México, entre otros, así como los del Virreinato del Perú, estuvieron compuestas, en gran medida, por la adición de ese tipo de viviendas. Aún más, si bien las celdas, como parte del conjunto conventual, pertenecían a la comunidad de religiosas, su construcción y su uso formaron, en la práctica, parte del dominio de lo privado. En este sentido, y de acuerdo con la costumbre, las monjas no adquirían

40. Que las celdas se identificaban con un tipo de casa-habitación ha sido señalado con claridad por Serrera y Figallo, op. cit., p. 304; Martha Fernández, "De puertas adentro: la casa habitación", en Antonio Rubial García (ed.), La ciudad barroca. Historia de la vida cotidiana en México, México, El Colegio de México/Fondo de Cultura Económica, 2005, vol. II, pp. 47-80; Ratto, op. cit., pp. I22-I 42. 
la propiedad, sólo ejercían el "usufructo" de ella. En un primer momento, las celdas fueron construidas por las familias de las monjas profesas; con el tiempo, a la muerte de sus "dueñas", la comunidad ejercía el derecho de propiedad sobre las celdas para que pudieran adquirirlas las nuevas aspirantes. Así, una y otra vez el dinero ingresaba a las arcas conventuales. En la medida en que la operación implicó la inversión de sumas considerables, se hizo necesaria una instancia notarial que garantizara los derechos de las partes involucradas - la comunidad conventual y la familia de la monja. El permiso para construir una celda o la aprobación para adquirir una que había quedado libre comportaba no sólo la solicitud de la monja y su familia, sino el visto bueno de la comunidad y la opinión final de las autoridades eclesiásticas. Asimismo, la mayoría de los trámites requería inevitablemente la intervención de uno o dos arquitectos, ya se tratara de efectuar la "vista de ojos" y el avalúo de la celda en venta, ya se tratara del arquitecto — contratado siempre por la familia de la religiosa- que levantaría la nueva o intervendría en la reparación y remodelación de la que había quedado libre. De esta manera, tanto los protocolos notariales como los trámites eclesiásticos revelan cuán generalizada era la práctica, así como permiten reconstruir este espacio fundamental de la estructura arquitectónica de los enormes conjuntos, y transparentan muchos detalles de la vida cotidiana dentro de la clausura.

Numerosos registros documentales sobre las celdas de San Jerónimo confirman que sus disposiciones y tamaños eran muy variables; desde pequeñas unidades formadas por un cuarto con cocina, hasta celdas de dos plantas, con varios cuartos, cocina, jardín, oratorio privado y azotea. ${ }^{4 \mathrm{I}}$ Así, por ejemplo, a principios del siglo xviII, Pedro de Arrieta —uno de los arquitectos más prolíficos de la ciudad y quien por entonces acababa de terminar la Basílica de Guadalupe $-^{42}$ realizó el avalúo de una celda que deseaba adquirir, en el Convento de San Jerónimo, el capitán Martín de Rojas y Amezola, para dos hijas profesas. El arquitecto describió la distribución de la celda y sus materiales. De su declaración surge que se trató de una verdadera casa habitación, cuya superficie cubría aproximadamente $\mathrm{I} 40 \mathrm{~m}^{2}$, sólo en planta baja. ${ }^{43}$ Según Arrieta,

4I. Ibidem, pp. I22-I 42, y gráficos 5, 6 y 7, pp. 425-433.

42. Martha Fernández, Artificios del barroco. México y Puebla en el siglo XVII, México, Universidad Nacional Autónoma de México-Coordinación de Humanidades, I990, p. 97.

43. Ratto, op. cit., p. I34. 
se compone su bivienda por la parte de abajo de dos quartos, un patinillo y corral de gallinas, escalera que da passo a un corredor, con puerta que da entrada a dos salas, con un corredorsillo que cae sobre dicho patinillo, un caracol de madera formada su caxa con tablones de xalocote y los pasos de la subida de dichos tablones, y da passo dicho caracol a una sala alta y oratorio, una soteguela con la mitad cubierta, y la otra mitad descubierta, los techos de todo referido sobre maderas de quartones, la pared maestra ynterior toda de piedra; que tiene de largo veinte baras que corre de oriente a poniente, con mas quatro baras que se incluien en el corralillo y patinillo, que son veinte y quatro en que esta fabricada la dicha vivienda; y de ancho siete baras entrando el gruesso de la pared, con mas un pedasillo de patio de seis baras de largo y seis de ancho en que esta fabricada dicha escalera y corredor [...] la escalera con sus pasos de piedra de tenaiuca sobre alfardas de madera de sedro el corredorsillo con su cubierta de madera de quartones [...] empedrado el pedasillo de patio de seis baras, un ornillo de dos baras y todo lo que a dicha selda toca y pertenese, haviendole dado el valor y presio asi al sitio como a su fabrica y a todo lo arriba mensionado; hallamos vale cantidad de mill y quinientos pesos, y assi lo juramos y declaramos por dios nuestro señor y la señal de la cruz, para que conste lo firmamos en Mexico a trese de noviembre de mil setezientos y trese años. 44

En igual medida, la información proveniente de las exploraciones arqueológicas realizadas en este convento confirman la existencia de un amplio conjunto de celdas con distinta distribución, comodidades y superficies. Uno de los ejemplos más notables es una celda de aproximadamente $230 \mathrm{~m}^{2}$, sólo en el primer nivel, formada por cinco cuartos de amplias dimensiones y dos jardines. Posiblemente construida durante el siglo XVIII, esta gran residencia se encontraba en el corazón de la zona habitacional del conjunto.

Casos aún más sorprendentes pueden documentarse en Jesús María. A partir de un plano levantado alrededor de 1775 por el arquitecto Francisco Guerrero y Torres, puede comprobarse que, durante el último cuarto del siglo XVIII, se habían construido tres celdas que ocuparon una superficie total de casi $\mathrm{I} 500 \mathrm{~m}^{2}$. Dos de ellas tuvieron una disposición muy similar y cubrieron una superficie aproximada de $300 \mathrm{~m}^{2}$. Cada una de estas verdaderas casas se componía de tres habitaciones en la planta baja y tres en la planta alta — distribuidas en torno a un patio-, con escalera y azotea. Contigua a ellas se levantó una extraordinaria celda de dos plantas que cubría casi I $000 \mathrm{~m}^{2}$. Organizada 
en torno a un patio central, la celda tenía en la planta baja un zaguán de acceso, capilla, cocina, bodega, "cuarto con placer" y escalera de dos tramos. En la planta alta, alrededor del claro del patio, tres corredores daban acceso a seis habitaciones, un cuarto para lavar y una azotea con arriates. ${ }^{45}$

De manera similar, los conventos de Santa Clara y Santa Catalina de Cuzco también se formaron a partir de la adición de muchas de tales celdas. Algunas debieron ser realmente grandes y cómodas. Los documentos relacionados con la adquisición y la reparación de estas celdas ofrecen una imagen del edificio como una estructura urbana compuesta por una serie de casas con cocinas, patios, gallineros y, en algunos casos, hasta por varios cuartos. Así, una gran parte de estos conjuntos conventuales podría asemejarse a vecindarios recorridos por calles y formados por la suma de "unidades independientes" de diversos tamaños y comodidades que, con frecuencia, los mismos documentos describen como "casas". ${ }^{6} \mathrm{Al}$ igual que en Nueva España, durante todo el periodo virreinal los documentos notariales confirman que las monjas de la ciudad de Cuzco adquirían esas celdas de acuerdo a las posibilidades económicas de sus familias. Así, por ejemplo, los protocolos informan de una celda en el Convento de Santa Catalina que contaba con "despensa, horno y alacena";47 al mismo tiempo que dejan constancia de cómo en 1806 una monja próxima a profesar adquirió una "casa bastante cómoda con ocho cuartos y su respectivo oratorio". ${ }^{48}$

A este respecto, los testimonios sobre los conventos de Lima no son menos abundantes. Al igual que en Cuzco y en la capital novohispana, los conjuntos se formaron en la medida que las monjas profesas hacían construir sus celdas, las que, con el correr del tiempo, pasaron de generación en generación y de familia en familia. De este modo, en la práctica surgió un verdadero mercado de compraventa de propiedades dentro de los conventos. Por ejemplo, en I620,

45. Cfr. Nuria Salazar Simarro, "Arquitectura elitista en un conjunto conventual femenino", Historias, México, Instituto Nacional de Antropología e Historia, núm. 38, 1997, pp. 55-67; "Repercusiones arquitectónicas en los conventos de monjas de México y Puebla a raíz de la imposición de la vida común", en Arte y coerción. Primer Coloquio del Comité Mexicano de Historia del Arte, Louise Noelle (ed.), México, Universidad Nacional Autónoma de México-Instituto de Investigaciones Estéticas, 1992, pp. I23-I 47.

46. Burns, op. cit., pp. I06-107.

47. Ibidem, p. I07; Archivo Departamental del Cuzco, Lorenzo de Messa Andueza, I656, ff. IOI-IO2, io de enero de 1656.

48. Ibidem, p. I07; Archivo Arzobispal del Cuzco, LXI, 3, 53. 
Francisco Ramos Galván, prominente juez de la audiencia, decidió regalar una celda a sus tres hijas próximas a profesar en el Convento de la Santísima Trinidad de Lima. Con este fin, por la nada despreciable suma de I 200 pesos, compró un solar dentro de la clausura donde se construiría la vivienda. En ella habitarían por el resto de sus vidas las tres hermanas, además de la correspondiente servidumbre. 49

$\mathrm{Al}$ respecto, ningún ejemplo resulta más elocuente que el Convento de Santa Catalina de Arequipa. En él todavía se conserva gran parte de las casas de distintos tamaños que formaron la gran zona habitacional, la cual contiene desde pequeñas casitas de dos cuartos hasta viviendas de cuatro o cinco habitaciones con patio y azotea. Algunas de ellas todavía tienen el escudo familiar de sus habitantes labrado en la puerta de acceso principal. ${ }^{50}$

En síntesis, la estructura arquitectónica de los conventos transparenta la complejidad, tanto como la riqueza y variedad de la vida conventual en uno y otro punto del imperio español. En primer lugar, resulta claro que, en términos de proporción y distribución, los espacios comunes fueron marcadamente menores respecto a los espacios privados dentro de los conjuntos. Las celdas ocuparon las áreas más extensas de los edificios. En segundo lugar, dentro de esos espacios - formal y funcionalmente privados-, las religiosas comían, dormían y pasaban su tiempo libre; en definitiva, en ellos transcurría una parte considerable de sus vidas. La costumbre de que varias mujeres de una misma familia — por razones no sólo religiosas sino sobre todo socioeconómicas - profesaran y habitaran en una misma celda dio origen a las "familias conventuales". ${ }^{\text {SI }}$ Las celdas no sólo establecieron círculos afectivos, como ám-

49. Martín, op. cit., p. I8I; Biblioteca Nacional del Perú, escritura de venta otorgada por la abadesa y monjas del Monasterio de la Santísima Trinidad, MS Z215.

50. Serrera y Figallo, op. cit., pp. 299-300.

5I. Los conventos de monjas virreinales, al igual que sus contemporáneos de la Europa católica, más allá de su función religiosa específica, fueron instituciones que respondieron a necesidades sociales y económicas. Tanto en el Viejo como en el Nuevo Mundo surgieron como los refugios para las "bien nacidas", las mujeres de las elites para las que sólo había dos opciones: el matrimonio o el convento. La elección se supeditaba a los intereses familiares; en consecuencia, por lo general, no fue algo que resolvieran las propias mujeres. Así, la profesión religiosa y el matrimonio fueron asuntos cuidadosamente planeados. En particular, Asunción Lavrin y Antonio Rubial han comenzado a estudiar la conformación de "familias conventuales" en la Nueva España. Luis Martín ha estudiado el fenómeno en los conventos peruanos. Asunción Lavrin, "Vida conventual: rasgos históricos”, en Sara Poot Herrera (ed.), Sor Juana y su mundo, México, El Claustro de Sor Juana, I995, pp. 35-9I; Antonio Rubial, "Un caso raro. La vida y desgracia de sor Antonia de San Joseph, 
bitos domésticos y privados, también abrieron paso a diferentes hábitos alimenticios, comodidades cotidianas y formas de vestir que excedían las normas religiosas. Aún más, de acuerdo también con el rango social y las posibilidades económicas de sus moradoras, en estas casas convivían mujeres de estado religioso y laicas. Las monjas contaron con esclavas y sirvientas y, en algunos casos, alojaron a parientas más o menos cercanas que, por distintos motivos, se encontraban desamparadas. En este sentido, las celdas fueron la expresión, dentro del espacio de la clausura, de las diferencias estamentales y económicas y, en igual medida, también reflejaron los profundos lazos de las monjas con las sociedades urbanas a las que pertenecían.

Estas "familias conventuales" surgieron desde la fundación de las comunidades y la práctica perduró hasta las primeras décadas del siglo XIx. En algunos casos, los "clanes" fundadores mantuvieron su cohesión durante varias generaciones; en otros, surgieron a partir de la profesión de varias mujeres emparentadas por lazos consanguíneos directos; pero en todos la celda, como espacio privado, fue la base física en que tomó cuerpo un complejo conjunto de prácticas cotidianas que, en muchos sentidos, rebasaron al conjunto de normas eclesiásticas instituidas por reglas, constituciones y preceptos pastorales.

En uno y otro punto del imperio, durante todo el periodo virreinal, se multiplicaron los ejemplos que confirman una tradición establecida en la práctica. El Convento de San Jerónimo de la ciudad de México fue fundado por los Guevara-Barrios, descendientes de una hermana de la primera mujer de Hernán Cortés y de uno de los más poderosos encomenderos del siglo xvI. Los hermanos Isabel y Juan de Guevara invirtieron una suma considerable en la compra de la extensa propiedad, y dotaron a la nueva institución. En ella ingresaron no sólo doña Isabel — quien fue priora— sino sus tres hermanas; años más tarde, profesaron también al menos dos mujeres pertenecientes a ramas colaterales de la familia. ${ }^{52}$ En igual medida, a comienzos del siglo XVII el Convento de la Encarnación de Lima alojó a siete monjas de un mismo linaje, todas emparentadas en primer grado con los Garabito-Illescas. Cuatro de ellas eran hermanas de doña Isabel de Illescas, una prominente señora de la sociedad limeña, casada con el doctor Francisco de León Garabito. A ellas

monja profesa en Jesús María”, en Manuel Ramos Medina (ed.), El monacato femenino en el imperio español. Memorial del II Congreso Internacional, México, Condumex-Centro de Estudios de Historia de México, I995, pp. 35 I-358; Martín, op. cit., pp. 192-200.

52. Ratto, op. cit., pp. 190-223. 
se sumaron las tres hijas del matrimonio. Las siete, más una serie de primas y parientes lejanas, vivieron dentro de la clausura de acuerdo a su rango social y económico. Sobre todo, tuvieron cómodas celdas vecinas, con sus esclavas y sirvientas, y conservaron sus lazos familiares y afectivos. ${ }^{53}$ Aún más, todo indica que, hacia finales del siglo XVIII, la costumbre continuaba vigente en ambas capitales. Así, en San Jerónimo, la marquesa de Selva Nevada contrató a Ignacio Castera - uno de los arquitectos más renombrados de finales del siglo XVIII - para que construyera una celda destinada a dos de sus hijas. Sin duda se trató de una vivienda con capacidad suficiente para alojar al menos a cuatro monjas; dado que, al momento de profesar, la primera hija de la marquesa hizo constar que la celda había sido pagada por su madre para ella, dos hermanas y una sobrina, además de las mujeres de la familia que con posterioridad decidieran tomar estado en el Convento de San Jerónimo. ${ }^{54}$ De manera similar, cuatro hijas del general Juan de la Fuente Rojas disfrutaron de una de las mejores celdas del Convento de Santa Catalina de Lima. En ella vivieron, además, tres generaciones de sobrinas que quedaron a cargo de las religiosas hasta tomar estado - mientras no se les concertara un matrimonio apropiado o se arreglara su profesión en el mismo convento. 55

No sólo la estructura de los conventos virreinales transparenta que su vida interna fue rica en contrastes. La posibilidad de que las monjas dispusieran de este tipo de espacio habitacional se relacionó directamente con un modo de vida que, en muchos aspectos, se apartó de reglas y preceptos pastorales. $\mathrm{Al}$ vivir en "núcleos familiares" y disponer de rentas personales, las monjas reprodujeron el nivel de vida y las costumbres de sus casas paternas. Las dimensiones de las celdas, la comida e incluso detalles de coquetería en el vestir variaron de acuerdo con la posición de cada religiosa. Así lo atestiguan las visitas episcopales de los arzobispos de México y Lima durante el siglo Xviı. ${ }^{56}$

53. Martín, op. cit., p. I93.

54. Archivo de Notarías de la ciudad de México, José Antonio Montes de Oca, notaría 4I7, vol. 274I, año I79I, ff. I6 y 3 I 2 .

55. Martín, op. cit., pp. 195-196.

56. La visita de los prelados a los conventos de monjas bajo jurisdicción ordinaria fue un instrumento de control espiritual y administrativo implementado desde la Edad Media tardía y renovado por el Concilio de Trento. Dentro del ámbito virreinal, la visita se reglamentó particularmente en el Tercer Concilio Provincial de Lima (I583) y en el Tercer Concilio Provincial Mexicano (I585). Los arzobispos y obispos tenían la obligación de supervisar cada convento bajo su jurisdicción. Debían examinar los edificios y las finanzas de las comunidades, velaban por la correcta práctica 
Los autos que los prelados emitieron revelan la dicotomía que existió entre la norma y la práctica en la vida cotidiana de los conventos virreinales.

La visita del arzobispo fray Payo Enrique de Rivera a las comunidades bajo su jurisdicción durante 1673 permite reconocer algunos usos de los espacios conventuales. Así, por ejemplo, tras la inspección del Convento de San Jerónimo - y de otros de la capital novohispana-, el arzobispo intentó controlar el uso de los locutorios y su función como espacio de abierta socialización. ${ }^{57} \mathrm{Al}$ mismo tiempo, llamó la atención sobre ciertos problemas en el uso de los espacios comunes. Si bien resulta claro que en San Jerónimo — al igual que en el resto de los conventos de vida particular- se mantuvo una clara delimitación entre el núcleo conventual y la zona habitacional, fray Payo detectó algunas irregularidades.

Y porque combiene que las viviendas que son comunes a todas las religiosas como son dormitorio, sala de labor, nobiçiado y enfermería, sólo sirban de aquellas cosas para que están destinadas, mandaba y mandó a dicha madre priora que es y en adelante fuere no permita que en ellas se haga avitasión de ninguna religiosa particular, y que especialmente se observe lo referido en la enfermería y que no haviendo enferma en ella se sierre y guarde la llabe la dicha madre priora sin permitir cosa en contrario. ${ }^{58}$

De las recomendaciones de fray Payo resulta claro que en muchos conventos el crecimiento de la zona habitacional amenazó al núcleo conventual. Sin duda, esto se relaciona con el aumento constante de la población, circunstancia que probablemente conllevó más de un problema. Si se considera que los conjuntos estaban confinados a los límites del predio, era casi imposible que la superficie disponible creciera de acuerdo con las necesidades. Así, puede conjeturarse que, a la menor distracción de los prelados, las monjas decidieran convertir los espacios comunes en celdas, sobre todo por la rentabilidad económica que esto implicaba.

del culto y verificaban la observancia de la vida religiosa. Todo el proceso se registraba por escrito en documentos que hoy constituyen una fuente muy rica de información.

57. Leticia Pérez Puente et al. (eds.), "Autos de la visita que el yllustrisimo y reverendisimo señor maestro don fray Payo de Ribera, arçobispo de este arçobispado de México, del consejo de su magestad mi señor hizo en el sagrado combento de san Gerónimo de esta çiudad", en Autos de las visitas del arzobispo fray Payo Enríquez a los conventos de monjas de la ciudad de México (1672-1675), México, Universidad Nacional Autónoma de México-Centro de Estudios Sobre la Universidad, 2005, f. I6v, p. II 4.

58. Ibidem, f. I $8 \mathrm{v}$. 
Los resultados de las visitas episcopales a los conventos de Lima muestran una situación muy similar. Los arzobispos una y otra vez amonestaron a las religiosas por el relajamiento general de la disciplina, el caos en los locutorios, las multitudes de esclavas y sirvientas que convivían libremente en las clausuras, el lujo de las celdas privadas, los entretenimientos no apropiados al estado religioso, el uso de joyas y accesorios mundanos sobre los hábitos y los excesivos gastos en la celebración de las fiestas conventuales, entre muchos otros problemas. ${ }^{59}$

La vida cotidiana que se hace visible en la arquitectura conventual fue diversa y compleja. Nada más elocuente que el testimonio de sor Juana Inés de la Cruz:

Lo que sí pudiera ser descargo mío es el sumo trabajo no sólo en carecer de maestro, sino de condiscípulos con quienes conferir y ejercitar lo estudiado, teniendo sólo por maestro un libro mudo, por condiscípulo un tintero insensible y en vez de explicación y ejercicio muchos estorbos, no sólo los de mis religiosas obligaciones (que éstas ya se sabe cuán útil y provechosamente gastan el tiempo) sino aquellas cosas accesorias de una comunidad: como estar yo leyendo y antojársele en la celda vecina tocar y cantar; estar yo estudiando y pelear dos criadas y venirme a constituir en juez de su pendencia; estar yo escribiendo y venir una amiga a visitarme, haciéndome muy mala obra con muy buena voluntad, donde es preciso no sólo admitir el embarazo, pero quedar agradecida del perjuicio. $Y$ eso es continuamente, porque como los ratos que destino a mi estudio son los que sobran de lo regular de la comunidad, esos mismos les sobran a las otras para venirme a estorbar; y sólo saben cuanta verdad es ésta los que tienen experiencia de vida común. ${ }^{60}$

De esta manera, la célebre monja novohispana enumeró las molestias cotidianas de la vida en congregación, señaló en qué medida ellas hacían del convento un lugar poco propicio para el estudio y, así, ofreció una pintura viva de la zona habitacional del Convento de San Jerónimo.

Si sor Juana presentó — desde el interior de la clausura - a su convento como un mundo complejo y diverso, otros dos testimonios del siglo XvII revelan que — desde el exterior-, sus mismos contemporáneos percibieron

59. Martín, op. cit., p. 232.

6o. Sor Juan Inés de la Cruz, "Respuesta a sor Filotea", Obras completas, México, Fondo de Cultura Económica, I995, vol. IV, pp. 450 y 45 I. 
esas extensas estructuras como "ciudades dentro de la gran ciudad". Refiriéndose al Convento de la Encarnación en Lima, Antonio Vázquez de Espinosa señaló: "La casa está bien fabricada y el sitio es tan grande, que si una criada se huye de su ama, pasan muchos días sin hallarla, porque tiene calles y barrios como un pueblo, de celdas tan cabales, como una casa con todos sus cumplimientos y oficinas". ${ }^{61}$

Una imagen similar brinda Carlos de Sigüenza y Góngora en la crónica del Convento de Jesús María. Haciéndose eco del testimonio de la madre Inés de la Cruz, señala que las monjas "en conventos grandes como el de Jesús María se pasan años sin que se hablen unas a otras". Y luego agrega: "siempre me han parecido los conventos grandes como un pueblo de muchas naciones". ${ }^{62}$

\section{Una reflexión final}

Aunque desde una perspectiva actual resulta difícil imaginarlo, las monjas, en muchos sentidos, fueron el centro de la vida urbana. A partir de los casos reseñados, todo parece indicar que los conjuntos conventuales podrían considerarse, más que edificios, estructuras de carácter urbano, insertas en el espacio de las grandes ciudades. En uno y otro punto del continente, los conventos de monjas virreinales se percibieron, sin duda, como ciudades dentro de ciudades. La importancia física de estas estructuras y la significación social de sus moradoras hicieron de estas instituciones — muchas veces relegadas por la historia del arte- tópicos fundamentales del orgullo cívico y, por tanto, símbolos de identidad cultural.

$\mathrm{Si}$ apenas se ha comenzado a explorar el tema de la arquitectura conventual femenina en los virreinatos de Nueva España y Perú, menos aún se han intentado visiones comparativas. Sin embargo, con sólo poner en correlación, desde una perspectiva general, casos de una y otra parte del continente, surgen puntos de confluencia muy sugerentes, puntos de partida para comenzar a repensar las geografías histórico-culturales desde una perspectiva integradora. \$े

6r. Vázquez de Espinosa, op. cit., pp. 302-303.

62. Sigüenza y Góngora, op. cit., ff. I 44 y I 45 v. 